\title{
Information access in high school libraries in Limpopo Province, South Africa
}

\author{
Maredi Samuel Mojapelo ${ }^{1}$ and Luyanda Dube $^{2}$ \\ mojapsm@unisa.ac.za and dubel@unisa.ac.za
}

\begin{abstract}
Received: 19 June 2014
Accepted: 7 December 2014
\end{abstract}

\begin{abstract}
School libraries help to support the school curriculum by providing learners and teachers with access to a wide variety of information resources, exposing learners to diverse ideas, experiences and opinions. Equitable access to information resources by teachers and learners is absolutely essential to enable them to execute their curriculum-related tasks and activities. Information access refers to an entire range of possibilities for making information and information services available to the users. Although access to services and collections is enshrined in the United Nations Universal Declaration of Human Rights and Freedoms it has emerged from the literature that only a few schools in South Africa have well-equipped and functional libraries, making accessibility to information resources a major challenge to the majority of the teachers and learners. A library's success depends upon the availability of information resources. It is not enough that a library houses information resources; what is important is that they are physically and intellectually accessible to those who need them. The purpose of this study was to investigate information access by teachers and learners in high schools in the Limpopo province. The study was largely quantitative, blended with the triangulation of both quantitative and qualitative methods for data collection. Self-administered questionnaires were used to collect quantitative data from principals and teacher-librarians whilst an interview schedule was used to collect qualitative data from education officials. The findings established that access to information by teachers and learners is a daunting challenge in the majority of the schools. The study recommends that the National Guidelines for School Library and Information Services (2012) be converted into a legislated school library policy to ensure functionality of the different school library models to improve information access for curriculum support.
\end{abstract}

Keywords: School libraries, information access, library-based resources, information services, Limpopo Province.

\section{Introduction and background to the study}

A vibrant, vigorous and dynamic school library is indispensable in modern education in order to support curriculum obligations. The school library is intended to be an information- seeking and learning environment, which provides up-todate information that will keep teachers and learners abreast of new developments (Manjunatha 2003; Meyers, Nathan, \& Saxton 2007). School libraries are repositories of information resources and play an important role in supporting learners with curriculum-related tasks and activities such as homework, assignments and research projects. It is not enough that a library houses information resources; what is important is that these resources are physically and intellectually accessible to those who need them (Bernard \& Dulle 2014; Ugah 2007). Libraries in general have a responsibility to facilitate access to and use of information resources and services. A library's usefulness and success depends upon the availability, accessibility and usability of its information resources. Information access refers to the strategies, modes or an entire range of possibilities used to make information and information services available to users (Manjunatha 2003). In the past, print resources dominated the information landscape, making the process of accessing information a relatively simple process of locating and extracting the required information. With the emergence of information technologies predominant in the knowledge economy, the scene has changed, offering a lot of possibilities for accessing various types and formats of local and virtual information and information services.

In South Africa, the school library system is underdeveloped: only $7.2 \%$ of schools have functional school libraries (The National Education Infrastructure Management System [NEIMS] 2011; Nkondo et al. 2014). According to the Limpopo province's annual survey (Limpopo 2012), the province has 1,437 public high schools distributed in both urban and rural communities. However, only $2.3 \%$ of the schools have well-resourced and functional school libraries (Nassimbeni \& Desmond 2011; NEIMS 2011; Nkondo et al. 2014). As in other provinces, the majority of schools with wellfunctioning school libraries are historically advantaged (so-called Model C schools) in historically advantaged affluent communities, whilst, in historically disadvantaged and marginalised communities, schools libraries are virtually nonexistent (Mojapelo 2008). The former Model C schools are those which were earmarked for 'non-blacks' during the apartheid era. As stated by Hart (2013:49), the "so- called ex-Model C suburban schools ... are able to supplement their government budgets by levying extra fees from their largely middle-class parent bodies". Unfortunately, this state of affairs widens the already-existing divide between the "haves and have nots" which goes against the grain of the South

1. Samuel Mojapelo is a Lecturer in the Department of Information Science, University of South Africa

2. Luyanda Dube is Professor in the Department of Information Science, University of South Africa 
African constitution that upholds equal rights for all. Dubazana and Hoskins (2011) affirm that there are enormous disparities between these schools and the provision of resources. However, the Library and Information Services (LIS) Transformation Charter (Nkondo et al. 2014:47) states that:

Good school LIS are essential to the transformation of the South African education system, which aims to provide quality schools for all South African learners. Apartheid's Bantu education calculatedly under-resourced the schools designated for black learners. If school libraries are deemed to be important for quality learning, then the principles of redress and equity enshrined in the South African Constitution and educational legislation mean that ways must be found to provide them. The daunting backlogs in provision mean that innovative models of service and delivery will be required. It is unrealistic to expect all 25,000 schools to be provided overnight with its own library facility. Any new models will, however, have to convince those who believe that only a centralised library in every school will fulfill the criteria of redress and equity.

In their studies, various researchers such as Du Toit (2008), Du Toit and Stilwell (2012), Equal Education (2011), Ocholla (2009) and Paton-Ash and Wilmot (2013) highlight that the national and provincial education departments in South Africa have made several attempts to address the shortage of school libraries in the country. Such attempts include the development of school library policy frameworks and guidelines. However, in South Africa, to date (2014), the national Department of Basic Education does not have a legislated school library policy even though five drafts have been generated since 1997. This means that all attempts and efforts are in vain. Du Toit and Stilwell (2012:124) reaffirm that,

School library policy development in South Africa seems to be a series of missed opportunities and even though the process has been ongoing since 1997, no policy has been formally approved as yet.

Nevertheless, some provinces such as KwaZulu-Natal, Mpumalanga and Free State have developed and endorsed their own school library policies without a legislated national school library policy (Paton-Ash \& Wilmot 2013). Limpopo, like Gauteng, has a discussion document or a draft of a school library policy. Clearly, there is evidence that nothing much has been achieved in the policy development front and this fact compromises the impact and mandate to enforce the establishment of an appropriate and available school library model. However, the LIS Transformation Charter (Nkondo et al. 2014:51) recommends that:

A national school library policy that provides norms and standards for the establishing, provisioning and staffing of libraries is the first step to redress the situation. It will act as an impetus for provincial education departments to recognise the need for libraries and will provide authority for the work of the school library support services. It will also persuade schools' governing bodies to develop their own library and information policies.

This statement implies that an endorsed national school library policy is imperative for a country to roll out an active, vibrant and sustainable library system for all schools. Such a policy is is even more important in South Africa where the education system is characterised by huge historical disparities in resource-provisioning due to past apartheid practices.

\section{Research questions}

The purpose of this study was to establish the extent to which information is made accessible in public high schools of Limpopo Province for teachers and learners to execute their curriculum-related tasks and activities. The study attempts to answer the following research questions:

- Which school library models have been adopted by the public high schools to ensure that teachers and learners have access to the information resources for curriculum-related tasks and activities?

- To what extent are these school library models effective?

- What are the alternative information services available to teachers and learners?

\section{Research methodology}

The target population from which the sample was drawn comprised all public high schools in Limpopo Province. According to the Limpopo Department of Basic Education (Limpopo 2012), there are 1,437 registered public high schools which are scattered in the five districts of the province, namely, Vhembe, Mopani, Greater Sekhukhune, Waterberg and Capricorn. However, the study targeted only twenty-five public high schools which formed a sample. Within the sampled schools, the study specifically targeted teacher-librarians and principals.

As schools are located either in rural or urban communities, it was necessary to categorise them in this study in order to ensure a representative sample. To achieve this representative sample, two sampling methods were used, namely stratified and systematic random sampling. Firstly, the stratified sampling technique was applied (Keyton 2011). Two lists of schools were compiled: a rural school list and an urban school list. The aim was to draw public high schools from various socio-economic backgrounds and to ensure equal spread of schools in both strata in a sample. Secondly, the systematic random sampling technique was adapted to both rural and urban school sampling frames to ensure fair 
distribution and selection of schools in each stratum (Walliman 2011). From a total of 1,211 rural schools, a school numbered twenty was selected randomly as a starting point. With a standard interval of sixty-seven, the following schools were selected for inclusion in the sample: twenty; eighty-seven; $154 ; 221 ; 288$; until eighteen schools were chosen.

From the urban school list of 226 schools, a school numbered nine was selected randomly as a starting point. With a standard interval of thirty-two, the following numbered schools were selected for inclusion in the sample: nine; forty-one; seventy-three; 105; 137; until seven schools were selected. In the end, twenty-five rural and twenty-five urban public high schools formed the sample size. Self-administered questionnaires with self-addressed envelopes were separately mailed to the twenty-five teacher-librarians and twenty-five principals. There was a response rate of twenty-three (92\%) teacherlibrarians and twenty-two (88\%) principals. Other respondents in the study included three education officials, that is, one senior manager and two chief education specialists from the School Library and Information Services, Department of Basic Education, Polokwane, who were selected through convenience sampling. An interview schedule was used to conduct face-to-face interviews to obtain qualitative data from the respondents.

\section{Presentation and discussion of the findings}

The findings are presented thematically.

\subsection{Library models adopted by schools}

The study sought to investigate the types of school libraries of which the school principals were aware and types of structures used by the teacher-librarians to house library and information resources. On the two questionnaires, lists of school library models were provided and respondents were requested to mark or tick applicable block(s). Space was provided for "other" types of school library models. The information was cross tabulated as indicated in Table 1.

Table 1 School library models

\begin{tabular}{ccccc}
\hline Types of school library models & $\begin{array}{c}\text { Number of } \\
\text { principals }\end{array}$ & $\%$ & $\begin{array}{c}\text { Number of teacher- } \\
\text { librarians }\end{array}$ & \% \\
\hline Classroom converted into school libraries & 18 & 82 & 12 & 52 \\
Central library & 14 & 64 & 3 & 7 \\
Staffroom or office converted into a library & 4 & 18 & 2 & 30 \\
Collections of books kept in boxes in classrooms & 3 & 14 & 3 & 0 \\
Mobile trolleys in various classrooms & 2 & 9 & $\mathbf{3}$ & $\mathbf{2 3}$ \\
Storeroom & 2 & $\mathbf{1 0 0}$ & $\mathbf{1 0 0}$ \\
\hline
\end{tabular}

From Table 1 it is evident that a popular school library model is the classroom converted into a school library as indicated by the majority (eighteen; $82 \%$ ) of the school principals. It is not surprising, as more than half (twelve; $52 \%$ ) of the teacher-librarians indicated that they use this model to accommodate library and information resources in their schools. The use of this model is not unique to South Africa; for example, there is evidence that the model is being used in Uganda (Magara \& Batambuze 2009) and Nigeria (Adebamowo 2011; Petters \& Ottong 2012).

Although a central library model was the second most well-known school library model according to principals (fourteen; 64\%), only three (13\%) teacher-librarians indicated that their schools use the model to house library resources. National Guidelines for School Library and Information Services (Department of Basic Education 2012:14) clearly defines a central school library as:

An adequately stocked school library which provides learning resources and reading or reference material for all learning areas and or subjects offered by the school, as well as an extensive range of fiction and non-fiction reading material for a range of reading levels and, in addition, is actively utilized throughout the day and afternoon, constitutes an effective model to provide a dynamic School Library and Information Service. A teacher-librarian or a dedicated trained person must accept overall responsibility for the management of the library and be supported by a library assistant, a library committee and must work in cooperation with the School Management Team (SMT). It is from this centralized collection that all classroom libraries and block loans are administered.

Historically, this model was used by few advantaged so-called Model $\mathrm{C}$ schools in historically advantaged urban communities earmarked for White, Coloured and Indian learners during the apartheid era. It is therefore not surprising that very few schools, particularly in historically disadvantaged and marginalised communities, have this type of school library model. Hart and Zinn (2007) point out that in the mid-1980s, schools in the white sector of education were generously provided with centralised school libraries perhaps equal to any in the world, whereas libraries in black schools were virtually non-existent. Bikos and Papadimitriou (2013) point out that in Greece only a minority of private schools 
have decent school libraries, a trend evident elsewhere during the colonial era. In Kenya, schools earmarked for Europeans had collections of superior quality because they were developed as a result of colonialism and according to British standards (Boelens, Boekhorst \& Mangale 2012).

Although a staffroom or office converted into a library is the third most well-known school library model as indicated by the four (18\%) principals, seven (30\%) teacher-librarians indicated that the model ranks second biggest after classroom libraries where library resources are housed in schools. Noticeably, least-known school library models are storeroom and mobile trolleys in various classrooms selected by only two (9\%) principals each. The storeroom library model is used by only three (13\%) teacher-librarians. This school library model is also used by schools in Kenya (Boelens, Boekhorst \& Mangale 2012) and Greece (Bikos \& Papadimitriou 2013) to accommodate library and information resources. Graboyes (2012) reports that at George C. Marshall High School, in Fairfax County, Virginia, a cluttered storage room was transformed into a special collections room.

No school in the study uses mobile trolleys as a school library model, and only a few (two; 9\%) teacher-librarians indicated that they have collections or boxes of books in different classrooms. Use of book collections is reaffirmed by Adeyemi (2010) who indicates that $23 \%$ of all Namibian schools have book collections of some sort. These are typical characteristics of the schools in historically remote, rural and disadvantaged communities or villages and townships which generally do not have well-functioning central school libraries; another effect felt by people in those communities because of past apartheid legislations. However, it is encouraging to note that countries such as Uganda use other school library models such as library corners (Magara \& Batambuze 2009). It is also interesting to note that alternative school library models are emerging in other countries as a result of apparent lack of central school libraries. In Uganda, for example, the National Book Trust of Uganda under the East African Book Development Programme is assisting schools to set up reading tents in schools to encourage children to read for pleasure (Magara \& Batambuze 2009). As the majority of schools in South Africa do not have functional school libraries, improvisation is essential to give learners at least an opportunity to access information resources to learn or read. However, all three (100\%) education officials indicated that they encourage principals, members of school governing bodies, school management teams and teacher-librarians to adopt and implement any library model(s) suitable for prevailing conditions and circumstances at their schools.

When asked to suggest ways of improving the percentage of schools with school libraries, all the education officials indicated that they encourage schools to convert unused or extra classrooms into school libraries. Dr M.S. Makunyane High School in Seshego was cited as an example of a school where an extra classroom was converted into a library. The education officials also indicated that the province has two donated mobile library buses to provide library and information services to schools in three districts of the province, namely, Capricorn, Greater Sekhukhune and Mopani from April 2013. The education officials further stated that there are non-governmental organisations such as Room to Read and Rotary Clubs in Bedfordview, Gauteng and Middleburg that are dedicated to assisting schools to establish functional libraries.

When asked whether or not school libraries are spacious enough to allow teachers and learners to access and use library and information resources, out of twenty-three, most (seventeen; 68\%) teacher-librarians responded negatively. Accessibility to resources is severely hampered by lack of space to accommodate sufficient tables and chairs for users. Seventeen teacher-librarians who responded negatively to the previous question were asked to indicate what they do to address challenges of access and use of educational resources. Their responses are presented next.

Firstly, out of seventeen, six (35\%) teacher-librarians indicated that teachers are encouraged to borrow resources to use in classrooms, or both teachers and learners can borrow resources for home use or reading. It means that the majority of the teachers and learners cannot utilise library resources in the school libraries due to insufficient space. Secondly, only six (35\%) teacher-librarians indicated that due to congestion in rooms used as school libraries, such as staffrooms, storerooms or classrooms, nothing is being done to ensure that teachers and learners access and use library resources. Thirdly, only one (6\%) teacher-librarian indicated that because of high enrolments of learners at his or her school, no classroom can be converted into a library facility because of a shortage of classrooms for teaching and learning, while another one (6\%) indicated that due to space constraints, learners are grouped to access and use library resources. Very few (three; 18\%) teacher-librarians did not respond. When asked if the existing implemented school library models are evaluated for efficiency, all three (100\%) education officials reiterated that due to lack of personnel, school library models are not evaluated. This fact may imply that ineffective and inefficient library models are being implemented in schools, thus not benefiting teachers or learners. Du Toit and Stilwell (2012) argue that school library models should be assessed accurately with the aim of implementing the most appropriate and suitable models in particular schools. The one-size-fits-all approach is not applicable here. This knowledge will assist the relevant stakeholders in choosing, adopting and implementing relevant, appropriate and reliable school library models which are the best for their schools.

\subsection{Other types of information services}

The study sought to investigate whether or not teachers and learners can access and use library resources via other information services other than school libraries. The findings are indicated in Table 2.

\subsubsection{Public or community libraries}

When asked whether their schools are situated near a community or public library, as indicated in Table 2 , thirty-three (73\%) principals and teacher-librarians in total indicated a negative response. Only twelve (27\%) respondents in total indicated that their schools are situated next to public or community libraries. From this, one can deduce that very few teachers and learners in historically disadvantaged and marginalised communities have access to information resources 
in public or community libraries. Machet and Tiemensma (2009) admirably maintain that school and public or community libraries can play an important role in developing and promoting a reading culture and encouraging learners to read for pleasure. They point out that teachers and learners can access books and other printed materials in those facilities. They point out the role that public or community libraries can play in initiating story-telling programmes, book clubs and so on to encourage reading for the benefit of the learners in the province. Since public or community libraries stock a wide variety of library materials, they can encourage learners to read on their own voluntarily, which can encourage them to develop good reading habits and a reading culture, both of which are the basis for lifelong learning and independent study.

However, according to Hart (2012:1), "fewer than $10 \%$ of schools have functioning school libraries and millions of South Africans do not have access to public libraries" as libraries are still unevenly distributed across different communities. A study by Hart and Zinn (2007) showed that only $2 \%$ of the general public in rural KwaZulu-Natal have access to a public library. Only $10 \%$ of people in Limpopo have access to library and information resources in public or community libraries (Limpopo 2009). These percentages might indicate that learners from historically underprivileged and rural provinces are disadvantaged because they cannot gain the right to use library and information resources in public or community libraries to meet their curriculum-related requirements or needs. Machet and Tiemensma (2009) are of the opinion that, unfortunately, areas with social problems such as high levels of illiteracy, poverty and unemployment are also areas where public library services are either non-existent or of poor quality.

Machet and Tiemensma (2009) confirm that under the previous regime, library-resource provisioning in South Africa in the black townships, informal settlements and rural communities, was less favourable than that for white urban areas. They indicate that public libraries still serve primarily the educated and urban middle class, which is a small minority (less than $10 \%$ ) of the population.Tiemensma (2008) proposes transport as one of the obstacles obstructing many learners from accessing library resources in public or community libraries as the majority of libraries are still found in historically advantaged urban communities far from the majority of teachers and learners in historically disadvantaged, marginalised rural black communities. This is reaffirmed by Machet and Tiemensma (2009) who point out that many learners do not have transport to reach libraries, or money to pay for such transport.

When asked to indicate whether or not they could get a block loan for resources from their nearby public or community libraries, a minority (two; 40\%) of the five teacher-librarians near to their facilities responded positively. One can deduce that the relationship between schools and public or community libraries needs to be revived to enable teachers' access to block loan library resources to enhance the quality of teaching and learning in their schools. Those teacher-librarians who responded negatively were asked where else they could obtain a block loan; they cited the following: firstly, out of eighteen, five (28\%) teacher-librarians indicated that they obtain a block loan from public or community libraries in towns or cities some kilometres away from their schools. This means that the majority of the schools in Limpopo Province cannot obtain a block loan from public or community libraries because they are located far away from them. Secondly, only one teacher-librarian indicated that his or her school obtains a block loan from a special library (Tshikondeni Exxaro Coal Mine library). One respondent, a teacher-librarian, indicated that he or she obtains a block loan from Thengwe High School which has a well-resourced school library. Thirdly, one teacher-librarian who cannot obtain a block loan from public or community libraries indicated that teachers and learners are encouraged to use the internet instead, while two teacher-librarians indicated that they are doing nothing because public or community libraries are situated far from their schools.

\subsubsection{Multipurpose centres}

The researchers were determined to know from teacher-librarians specifically whether or not their schools are located near multipurpose centres. From Table 2 it is evident that out of twenty-three, twenty (87\%) teacher-librarians responded negatively. It should be noted that there are few multipurpose centres in Limpopo Province. Stilwell (2009) points out that learners in deep rural communities do not have access to libraries, regardless of the attempts by the government to provide services through multipurpose community centres. However, the study established that only a few (3\%) schools are situated near multipurpose centres, which enables teachers and learners to use library resources such as computers for instructional purposes. Although one respondent commented that there are very few resources in the multipurpose centres, only two respondents indicated that their teachers and learners use the computers in the multipurpose-centres for internet access. Kwake, Ocholla and Adigun (2006) are of the opinion that, although multipurpose community centres form the backbone of development of communication and the dissemination of information to needy and deprived communities, they lack effective management, well-maintained equipment, relevant information as well as the muchadvocated access to the internet.

\subsubsection{Education library services}

When asked whether teachers and learners can borrow materials from library services of the Department of Basic Education, it is evident from Table 2 that forty-three (96\%) respondents in total responded in the negative; an unfortunate situation as the education library services have appropriate and relevant resources which may enhance the quality of teaching and learning in schools because they are selected by professional library specialists. One can intimate that perhaps the marketing of the education library services must be done to schools to reveal the value they can play in education as resource centres. Only two principals indicated that their schools can borrow educational resources from the library services of the Department of Basic Education. 
Table 2 Alternative information services

\begin{tabular}{|c|c|c|c|c|c|c|c|}
\hline $\begin{array}{l}\text { Other types of } \\
\text { information } \\
\text { services available }\end{array}$ & Responses & $\begin{array}{l}\text { Number of } \\
\text { teacher- } \\
\text { librarians }\end{array}$ & $\%$ & $\begin{array}{l}\text { Number of } \\
\text { principals }\end{array}$ & $\%$ & $\begin{array}{c}\text { Cumulative } \\
\text { total }\end{array}$ & $\begin{array}{c}\text { Cumulative } \\
\%\end{array}$ \\
\hline \multirow{2}{*}{$\begin{array}{l}\text { Public or community } \\
\text { libraries }\end{array}$} & Yes & 5 & 22 & 7 & 32 & 12 & 27 \\
\hline & No & 18 & 78 & 15 & 68 & 33 & 73 \\
\hline \multirow{3}{*}{$\begin{array}{l}\text { Multipurpose } \\
\text { centres }\end{array}$} & Yes & 2 & 9 & & & & \\
\hline & No & 20 & 87 & & & & \\
\hline & Do not know & 1 & 4 & & & & \\
\hline \multirow{2}{*}{$\begin{array}{l}\text { Education library } \\
\text { services }\end{array}$} & Yes & 0 & 0 & 2 & 9 & 2 & 4 \\
\hline & No & 23 & 100 & 20 & 91 & 43 & 96 \\
\hline \multirow{2}{*}{ Other schools } & Yes & 2 & 9 & 1 & 5 & 3 & 7 \\
\hline & No & 21 & 91 & 21 & 95 & 42 & 93 \\
\hline \multirow{2}{*}{$\begin{array}{l}\text { Mobile library } \\
\text { services }\end{array}$} & Yes & 0 & 0 & & & & \\
\hline & No & 23 & 100 & & & & \\
\hline \multirow{3}{*}{ Internet } & Yes & 12 & 52 & 11 & 50 & 23 & 51 \\
\hline & No & 10 & 44 & 11 & 50 & 21 & 47 \\
\hline & Do not know & 1 & 4 & & & & \\
\hline \multicolumn{2}{|c|}{ Number of respondents } & 23 & 100 & 22 & 100 & 45 & 100 \\
\hline
\end{tabular}

\subsubsection{Other schools}

When asked whether they could borrow library materials from other schools in their area, the majority (forty-two; 93\%) of teacher-librarians and principals responded negatively, as indicated in Table 2. Inter-school library lending of resources will allow schools to share resources and to minimise duplicate purchases of resources as much as possible (Department of Basic Education 2012). Only three respondents in total indicated that they could borrow learning and teaching support materials from neighbouring schools. The researchers commend this practice as a step in the right direction and wish it could be extended to the lending of library and information resources and not textbooks only.

\subsubsection{Mobile library services}

The researchers wanted to know from teacher-librarians specifically whether or not their schools receive mobile library services. Unfortunately, all twenty-three teacher-librarians responded negatively. This situation is unfortunate taking into consideration the majority of the schools with non-functional school libraries in the province. However, all three education officials indicated during the interview that mobile library services will be introduced and implemented in schools in three districts of the province, namely, Capricorn, Greater Sekhukhune and Mopani as from April 2013 onwards. The introduction of mobile library services will be an advantage for learners in those districts because reading materials will enhance their reading skills which, in turn, will lead to improved literacy development. All three education officials were optimistic that the project could be extended to other districts when adequate funds are made available for the implementation. However, in mostly rural provinces such as Limpopo, the implementation of this innovative project will likely pose serious challenges. Efficient implementation of the mobile library services relies heavily on improved and tarred roads. A study by Mahwasane (2008) reveals problems associated with roads in the Limpopo province. The model is perhaps feasible in historically privileged urban communities where the majority of the roads are tarred and in good condition. Bikos and Papadimitriou (2013) point out that schools in Greece are supported by mobile libraries attached to the nineteen main public libraries.

\subsubsection{The internet}

The respondents were asked whether their schools have computers with internet access. As indicated in Table 2, twentythree $(51 \%)$ teacher-librarians and principals responded positively. Twenty-one (47\%) respondents in total responded negatively, regrettable considering the value of Information Technology (IT) in modern education and information-based societies. Apparently, the challenge is that the accompanying equipment is expensive and schools do not have the necessary funds. Another challenging factor is that most schools in Limpopo Province have been vandalised where criminals target computers and their accompanying technology. As the province is mostly rural, the majority of schools do not have access to the internet because of a lack of telecommunications infrastructure in some of the areas of the province. The NEIMS report (2011:25) indicates that out of 3,923 schools, only $426(11 \%)$ schools have computer 
centres. The majority $(3,497 ; 89 \%)$ thus lack computer centres. The report further indicates that only $167(4 \%)$ of the 3,923 schools surveyed have stocked computer centres. In rural schools, the percentage of schools with computers for instructional use is very low. Kwake, Ocholla and Adigun (2006:114) point out that, in their study, 41\% of respondents indicated that ICT services were not within reach of historically disadvantaged rural communities.

When asked of respondents with computers at schools, whether or not teachers and learners can use them for teaching and learning purposes, they responded as follows: firstly, out of a total of twenty-three, eight (35\%) respondents indicated that only teachers can access the internet due to space constraints in their library facility. Secondly, eleven $(48 \%)$ respondents indicated that both teachers and learners can use computers for teaching and learning at their schools because they are offering IT, Computer Studies and Computer Applications Technology as subjects. So, nearly half of the teachers and learners have access to computers and internet for teaching and learning in these schools. Only one respondent indicated that teachers and learners download question papers and memoranda from the internet. The same respondent also indicated that learners are encouraged to use cellphones to connect to the internet for learning purposes. Another respondent indicated that, due to space constraints, a limited number of teachers and learners are allowed into the facility to use computers for teaching and learning. One principal indicated that teachers and learners access one computer for internet use in his or her office. The same respondent added that in future, "teachers and learners will access computers in the computer laboratory with twenty-five workstations". The respondent further indicated that currently computers in the computer laboratory are not networked and not connected to the internet. Another respondent commented that teachers and learners lack IT skills to use computers to access and retrieve information. Thirdly, while one respondent indicated that learners are grouped to use computers for learning, another one did not answer. All three education officials indicated that security is a problem in most schools. They indicated that computers and their accompanying technologies are stolen, thus discouraging teachers and learners to acquire IT skills even though they are considered indispensable in modern education and information-based society. Security concerns or problems in school libraries are also raised by different researchers. Moswela (2010:16) confirms that "continued neglect of security in Botswana libraries will affect the quality of the school products and this can negatively affect the economic workforce of the country". Mojapelo and Fourie (2014:144) reaffirm that "as some schools are vandalised and school property is stolen, all public schools should have security measures in place”.

\section{Summary of the findings}

The main argument of this study is that the majority of teachers and learners in historically disadvantaged and marginalised rural communities of Limpopo Province lack equitable access to library and information resources which are indispensable to meet their curriculum obligations and needs. The findings establish that very few schools have wellresourced and well-stocked central libraries managed by full-time teacher-librarians. Inadequate and non-functional library systems in the majority of the schools is a stumbling block hindering all efforts to ensure efficient and equitable access to the information resources essential for learners to execute their assignments, homework, portfolios and research projects. Equally, teachers need pertinent educational resources to ensure detailed and systematic planning of lessons. In historically advantaged urban communities, teachers and learners are privileged because, where school libraries are inadequate or non-functional, they can access a plethora of information resources in other information services such as public or community libraries, multipurpose centres, tele centres, internet cafes and education library services of the Department of Basic Education. In contrast, teachers and learners in the majority of the historically disadvantaged and marginalised rural communities battle to access information because active, vibrant and functional school libraries are virtually non-existent. The problem is exacerbated by a lack of, or inadequate, library and information services. In conclusion, an active, vibrant and sustainable school library system is essential in the province to allow teachers and learners to have equitable access to library and information resources to meet and fulfil their curriculum obligations and needs.

\section{Recommendations}

Based on the aforementioned findings of the mainly quantitative study in public high schools in Limpopo Province, some recommendations can be made:

- Schools should continue to be allowed to use any of the available, relevant and effective school library models. However, other school library models such as reading tents, library corners and reading bags should be introduced in schools. Consultative workshops should be provided by the officials of the Department of Basic Education (library specialists) from which relevant stakeholders can obtain advice and guidance in the selection and implementation of the chosen school library models to promote access to the library and information resources.

- Dedicated, knowledgeable and professionally qualified library staff should be appointed by the Department of Basic Education to promote accessibility to the information-based resources in different school library models.

- A certain percentage of the Norms and Standard Grant should be ring-fenced to enable schools to procure appropriate and relevant library resources to enhance quality education.

- Conditional grants should be increased to enable the Department of Sport, Arts and Culture to roll out sufficient community-based libraries to enable teachers and learners to access and augment the few available resources in their schools. 
- Resource-sharing should be encouraged amongst schools in a particular circuit to avoid fruitless expenditure of duplicating library resources in schools. School library facilitators can assist by running consultative workshops and seminars amongst the stakeholders on inter-library loans amongst schools.

- Use of cellular phone technology should be encouraged in schools specifically to download teaching and learning materials indispensable for curriculum delivery.

- The National Guidelines for School Library and Information Services (2012) should be amended and converted into a legislated school library policy so that school library standards can be effectively implemented by the schools and the Department of Basic Education to ensure functionality of the different school library models in order to improve information access for teachers and learners for curriculum support.

\section{References}

Adebamowo, O. 2011. The use of school library resources in Ogun State secondary schools: a study of selected secondary schools in ljebu North Local Government Area, Nigeria. Journal of Research in Education and Society, 2(1):113-121. [Online].

http://www.icidr.org/doc/ICIDR\%20PDF\%20contents/journal\%20of\%20research\%20in\%20education\%20and\%20soci ety/vol2\%20nos\%202\%20August,\%202011/the\%20use\%20of\%20school\%20library.pdf (22 October 2014).

Adeyemi, T.O. 2010. The school library and students' learning outcomes in secondary schools in Ekiti, Nigeria. Asian Journal of Business Management, 2(1):1-8. [Online]. maxwellsci.com/print/ajbm/v2-1-8.pdf (22 October 2014).

Ajegbomogun, F.O. and Salaam, M.O. 2011. The state of school libraries in Nigeria. PNLA Quarterly: the official publication of the Pacific Northwest Library Association, 75(3):1-4.

Benard, R. and Dulle, F. 2014. Assessment of access and use of school library information resources by secondary schools students in Morogoro Municipality in Tanzania. Library Philosophy and Practice (e-journal), Paper 1107. [Online]. http://digitalcommons.unl.edu/libphilprac/1107/.

Bikos, G.D. and Papadimitriou, P. 2013. School libraries in Greece: turbulent past, uncertain present, doubtful future. Proceedings of the 2nd International Conference on Integrated Information. 30 August-3 September 2012. Egaleo: Elsevier. 73: 73-80. DOI:10.1016/j.sbspro.2013.02.024.

Boelens, H., Boekhorst., A.K. and Mangale, D.N. 2012. School libraries for nineteen public primary schools in rural Kenya: a pilot study. [Online]. http://www.albertkb.nl/mediapool/60/608240/data/Kenya-School-Libraries-Report-20122.pdf (22 October 2014).

Department of Basic Education. 2012. National guidelines for school library and information services. Pretoria: Department of Basic Education.

Du Toit, M. and Stilwell, C. 2012. KwaZulu-Natal school library policy and its feasibility for implementation in the province. South African Journal of Libraries and Information Science, 78(2):120-131.

Du Toit, M. 2008. KwaZulu-Natal school library policy and its feasibility for implementation in the province. PhD thesis. University of KwaZulu-Natal Pietermaritzburg.

Dubazana, K. and Hoskins, R. 2011. Promoting equitable access to school libraries in KwaZulu-Natal: the role of the Education Library information and Technology Services (ELITS). Innovation, 42: 114-131.

Equal Education. 2011. We can't afford not to: costing the provision of functional school libraries in South African public schools. Elonwabeni, Cape Town: Equal Education.

Graboyes, A.S. 2012. A $21^{\text {st }}$ century library in a $20^{\text {th }}$ century space. Educational leadership, 69(4): 74-78.

Hart, G. and Zinn, S. 2007. The conundrum of school in South Africa. [Online]. http://www.sapartners.org/documents/schoollibraries.pdf. (15 July 2014).

Hart, G. 2012. Searching for new library models: two South African case studies of services to youth [Paper]. Satellite meeting, Libraries for Children and Young Adults, Finland. 9-10 August 2012.

Hart, G. 2013. How school libraries improve literacy: some evidence from the trenches. Mousaion, 31(1):47-60.

Keyton, J. 2011. Communication research: asking questions, finding answers. 4th edition. Boston: McGraw Hill.

Kwake, A., Ocholla, D.N. and Adigun, M.O. 2006. The feasibility of ICT diffusion and use amongst rural women in South Africa. South African Journal of Libraries and Information Science, 72(2):108-118.

Limpopo. Department of Basic Education. 2012. Annual Survey Update Master [Raw data]. Polokwane: Department of Basic Education. (Unpublished).

Limpopo. Department of Sport, Arts and Culture. 2009. The 2009/10 Draft Plan. [In-house planning document]. Polokwane: Department of Sport, Arts and Culture. (Unpublished).

Machet, M.P. and Tiemensma, L. 2009. The literacy environment in support of voluntary reading: a case study in Gauteng East and the Highveld Ridge Area. M. Inf. thesis. University of South Africa.

Magara, E. and Batambuze, C. 2009. Reading promotion programmes in primary schools: a study of school library management practises in Pallisa District in Uganda. Mousaion, 27(2): 108-127.

Mahwasane, N.P. 2008. Provision of library services to disadvantaged children in rural areas of the Limpopo Province. M. Inf thesis. University of South Africa.

Manjunatha, K. 2003. Information access in libraries. Annals of Library and Information Studies, 5(2): 85-90.

Meyers, EM., Nathan, LP. and Saxton, ML. 2007. Barriers to information seeking in school libraries: conflicts in perceptions and practice. Information research, 11(2). [Online]. http://www.informationr.net/ir/12-2/paper295.html.

Mojapelo, M.S. and Fourie, J.A. 2014. Library and information resources in the rural schools of the Limpopo Province: a small study. Mousaion, 32(2):124-149. 
Mojapelo, M.S. 2008. Library and information resources in the rural schools of Limpopo Province: a pilot study. M. Inf thesis. University of South Africa.

Moswela, B. 2010. Book security in senior secondary schools in Botswana: an imperative to quality education. SA-eDUC Journal, 7(1)16-25.

Nassimbeni, M. and Desmond, S. 2011. Availability of books as a factor in reading, teaching and learning behaviour in twenty disadvantaged primary schools in South Africa. South African Journal of Libraries and Information Science, 77(2):95-115.

National Education Infrastructure Management System (NEIMS). 2011. National Assessment Report (public ordinary schools). Contract EDO305 [Online]. http://www.education.gov.za/LinkClick.aspx?fileticket=hHaBCAerGXc\%3D\&tabid=358\&mid=180 (14 October 2012).

Nkondo, M., Brown, A., Dick, A., Hart, G., Molawa, S., Nassimbeni, M. Seleti, Y. and Teffo, L.J. 2014. Library and Information Services Transformation Charter [Draft]. Pretoria: Department of Arts and Culture (DAC) and National Council for Library and Information Services (NCLIS).

Ocholla, D.N. 2009. Are African libraries active participants in today's knowledge and information society? South African Journal of Libraries and Information Science, 75(1):20 - 27.

Paton-Ash, M. and Wilmot, D. 2013. The state of school libraries in South Africa, Journal of Education, 57: $127-162$.

Petters, J.S. and Ottong, E.J. 2012. Correlates of school library development in Calabar, Nigeria. Journal of Education and Practice, 3(12): 67-71.

Stilwell, C. 2009. Mapping the fit: library and information services and the national transformation agenda in South Africa, Part II. South African Journal of Libraries and Information Science, 75(1):01-11.

Tiemensma, L. 2008. The literacy environment in support of voluntary reading: a case study in Gauteng East and the Highveld Ridge area, M.Inf thesis. University of South Africa.

Ugah, AD. 2007. Obstacles to information access and use in developing countries. Library Philosophy and Practice (ejournal), Paper 160. Available: http://digitalcommons.unl.edu/libphilprac/160.

Walliman, N. 2011. Research methods: the basics. New York: Routledge. 